\title{
An Alternative Planning Perspective for Regional Growth and Development in Pakistan
}

\begin{abstract}
Akmal Hussain
In Pakistan, historically, regional economic disparity has been an important political issue. During the 1960's the economic disparity between East and West Pakistan fueled the movement for provincial autonomy in East Pakistan and subsequently the movement for national independence in what became Bangladesh in 1971. During the late 1970's and 1980's the issue of regional disparity between the provinces of what remains of Pakistan has acquired an explosive potential. However, this is an issue that has been charged by emotion, and it may be time now to begin a serious analysis to enable effective policy formulation to overcome the problem.
\end{abstract}

It is important to note that not only does the overall growth rate of provincial income vary between provinces but recent research suggests that there is also considerable inter-provinces but recent research suggests that there is also considerable inter-provincial variation in the level of poverty and changes over time. What is interesting is that the pattern of variation in the inter-provincial economic growth rates may not be congruent with the pattern of variation in the inter-provincial poverty levels. Therefore, the emotional charge of regional identities mobilised on the basis of differing regional economic growth rates could be mitigated by the fact that a province like the Punjab for example, with a relatively high provincial growth rate also has a relatively high level of poverty measured in terms of the percentage of population below specified calorific norms.

In this article we will briefly present some of the available evidence on regional economic disparities with respect to economic growth rates as well as the levels of poverty, in an attempt to begin formulating a policy framework within which more regionally equitable economic growth can be achieved in an era where rapid moves towards economic liberalisation are being accompanied by growing assertion of regional identities within a state structure that is evolving a democratic polity.

\section{The Mechanism and Nature of Regional Economic Disparity in Pakistan}

The early studies on regional disparities focused on economic inequality between East-West Pakistan. The first major study on regional disparity within (West) Pakistan was conducted by Hamid and Hussain in 
which they estimated district-level value added in large scale manufacturing and agriculture, and also district level economic and social infrastructure, for the period 1959-60 to 1969-701. (See Tables 1 to 4).

Table-1: Per Capita Income by Provinces at Constant 1959-60 Factor Cost

\begin{tabular}{lcccccc}
\hline & \multicolumn{2}{c}{$1959-60$} & \multicolumn{2}{c}{$1964-65$} & \multicolumn{2}{c}{$1969-70$} \\
\cline { 2 - 7 } & Rupees & Index & Rupees & Index & Rupees & Index \\
\hline West Pakistan & 358.69 & 100 & 436.47 & 100 & 513.63 & 100 \\
N.W.F.P. & 186.57 & 52 & 222.83 & 51 & 254.20 & 49 \\
Sindh & 506.23 & 141 & 641.66 & 147 & 758.40 & 148 \\
Balochistan & 293.29 & 82 & 330.65 & 76 & 354.48 & 69 \\
Punjab & 365.25 & 102 & 434.51 & 100 & 509.08 & 99 \\
\hline
\end{tabular}

Source: Naved Hamid and Akmal Hussain: Regional Inequalities and Capitalist Development: Pakistan Economic and Social Review, Special Issue, 1976.

Table-2: Provincial Contribution to Value Added in Large-Scale Manufacturing Industry (At Constant 1959-60 Factor Cost)

\begin{tabular}{lrrrrrr}
\hline & \multicolumn{2}{c}{$1959-60$} & \multicolumn{2}{c}{$1964-65$} & \multicolumn{2}{c}{$1969-70$} \\
\cline { 2 - 7 } & $\begin{array}{l}\text { Rupees } \\
\text { Million }\end{array}$ & $\begin{array}{c}\text { Index } \\
(\%)\end{array}$ & $\begin{array}{c}\text { Rupees } \\
\text { Million }\end{array}$ & $\begin{array}{c}\text { Index } \\
\text { (\%) }\end{array}$ & $\begin{array}{c}\text { Rupees } \\
\text { Million }\end{array}$ & $\begin{array}{c}\text { Index } \\
(\%)\end{array}$ \\
\hline N.W.F.P. & 64.9 & 5.6 & 148.9 & 5.9 & 278.9 & 6.9 \\
Punjab & 532.0 & 45.9 & 1082.0 & 42.9 & 1730.0 & 42.8 \\
Sindh & 556.3 & 48.0 & 1287.0 & 51.0 & 2021.0 & 50.0 \\
Balochistan & 5.9 & 0.5 & 5.0 & 0.2 & 16.2 & 0.4 \\
West Pakistan & 1159.0 & 100.0 & 2523.0 & 100.0 & 4042.0 & 100.0 \\
\hline
\end{tabular}

Source: Naved Hamid and Akmal Hussain: Regional Inequalities and Capitalist Development: Pakistan Economic and Social Review, Special Issue, 1976.

\footnotetext{
${ }^{1}$ Naved Hamid and Akmal Hussain: Regional Inequalities and Capitalist Development, The Case of Pakistan. Pakistan Economic and Social Review, Special Issue, Winter 1976.
} 
Table-3: Industrial Concentration - Karachi Gross Value Added in Large-Scale Manufacturing Rupees in Million (At Current Price)

\begin{tabular}{lcccc}
\hline & $\mathbf{1 9 5 4}$ & $\mathbf{1 9 5 9 - 6 0}$ & $\mathbf{1 9 6 4 - 6 5}$ & $\mathbf{1 9 6 9 - 7 0}$ \\
\hline Karachi & 211.0 & 448.0 & 1133.0 & 1820.0 \\
West Pakistan & 548.0 & 1159.0 & 2581.0 & 4811.0 \\
$\begin{array}{l}\text { Karachi as Percentage of } \\
\text { West Pakistan }\end{array}$ & 38.5 & 38.7 & 42.9 & 37.9 \\
\hline
\end{tabular}

Source: Naved Hamid and Akmal Hussain: Regional Inequalities and Capitalist Development: Pakistan Economic and Social Review, Specia1 Issue, 1976.

Table-4: Percentage Share of Large-Scale Manufacturing

\begin{tabular}{lrc}
\hline & $\mathbf{1 9 5 9 - 6 0}$ & $\mathbf{1 9 6 9 - 7 0}$ \\
\hline Karachi & 38.7 & 37.9 \\
First Five Districts (Excluding Karachi) & 34.7 & 29.7 \\
Second Five Districts & 10.5 & 15.1 \\
Third Five Districts & 6.0 & 6.9 \\
Remaining Thirty Districts & 10.1 & 10.4 \\
West Pakistan & 100.0 & 100.0 \\
\hline
\end{tabular}

Source: Naved Hamid and Akmal Hussain: Regional Inequalities and Capitalist Development: Pakistan Economic and Social Review, Special Issue, 1976.

The study showed that not only did inter-provincial inequality increase over time, but also the degree of inequality within provinces accentuated. What was interesting was that the regional disparity was positively correlated with the level of growth, i.e., the rank ordering of intra-provincial inequality was congruent with the rank ordering of provincial growth rates. The study indicated that when growth occurs within the framework of the market mechanism there is a cumulative tendency for the relatively developed regions to grow faster than the relatively less developed regions. The developed regions enjoy internal and external economies, and lower costs of production relative to other regions which make the initiating region cumulatively more advantageous for 
further investment. The specific factors underlying cumulative divergence in the attractiveness of regions for further investment and hence increased disparity in regional growth rates are: concentration of communications, banking facilities, public utilities, technical know-how, trained manpower, and maintenance facilities. Conversely, as growth is concentrated in the developed region, it pulls capital and skilled labour from the backward region, thereby adversely affecting the age composition, skill and capital endowment of the backward areas.

\section{Levels of Economic Development by Region}

The following Table-5 shows the comparative rankings of districts on the basis of each of the four major studies on regional development in Pakistan. It is seen that all four studies report similar results with respect to the infrastructure endowment of districts. Both the top ranking and the bottom ranking districts are consistent for all four studies, except for variations that are explicable on the basis of development diffusion. (For example, Sheikhupura has substantially improved its development ranking over time as the result of substantial increase in infrastructure facilities).

Table-5: Comparative Ranking of Districts

\begin{tabular}{|c|c|c|c|c|c|}
\hline Districts & $\begin{array}{l}\text { Helbock } \\
\text { Naqvi } \\
\text { Infrastruct- } \\
\text { ure of } \\
\text { Social } \\
\text { Develop- } \\
\text { ment } 1960\end{array}$ & $\begin{array}{l}\text { Hamid } \\
\text { Hussain, } \\
\text { and Atta } \\
\text { Infrastruct- } \\
\text { ure and } \\
\text { Production } \\
\text { Indices late } \\
1960\end{array}$ & $\begin{array}{l}\text { Pasha and } \\
\text { Hussain } \\
\text { Infrastruct- } \\
\text { ure and } \\
\text { Social } \\
\text { Developme } \\
\text { nt 1970" }\end{array}$ & $\begin{array}{l}\text { Qutub } \\
\text { Produc- } \\
\text { tion per } \\
\text { Capita } \\
\text { 1980's }\end{array}$ & $\begin{array}{l}\text { Qutub } \\
\text { Infras- } \\
\text { tructure } \\
1980 \text { 's }\end{array}$ \\
\hline Karachi & 1 & 1 & 1 & 1 & 1 \\
\hline Lahore & 2 & 2 & 2 & 28 & 4 \\
\hline Peshawar & 3 & 13 & 5 & 28 & 5 \\
\hline $\begin{array}{l}\text { Rawalpindi/ } \\
\text { Islamabad }\end{array}$ & 4 & 3 & 3 & 14 & 2 \\
\hline Quetta & 5 & 30 & 4 & 36 & 3 \\
\hline Hyderabad & 6 & 15 & 6 & 6 & 7 \\
\hline
\end{tabular}




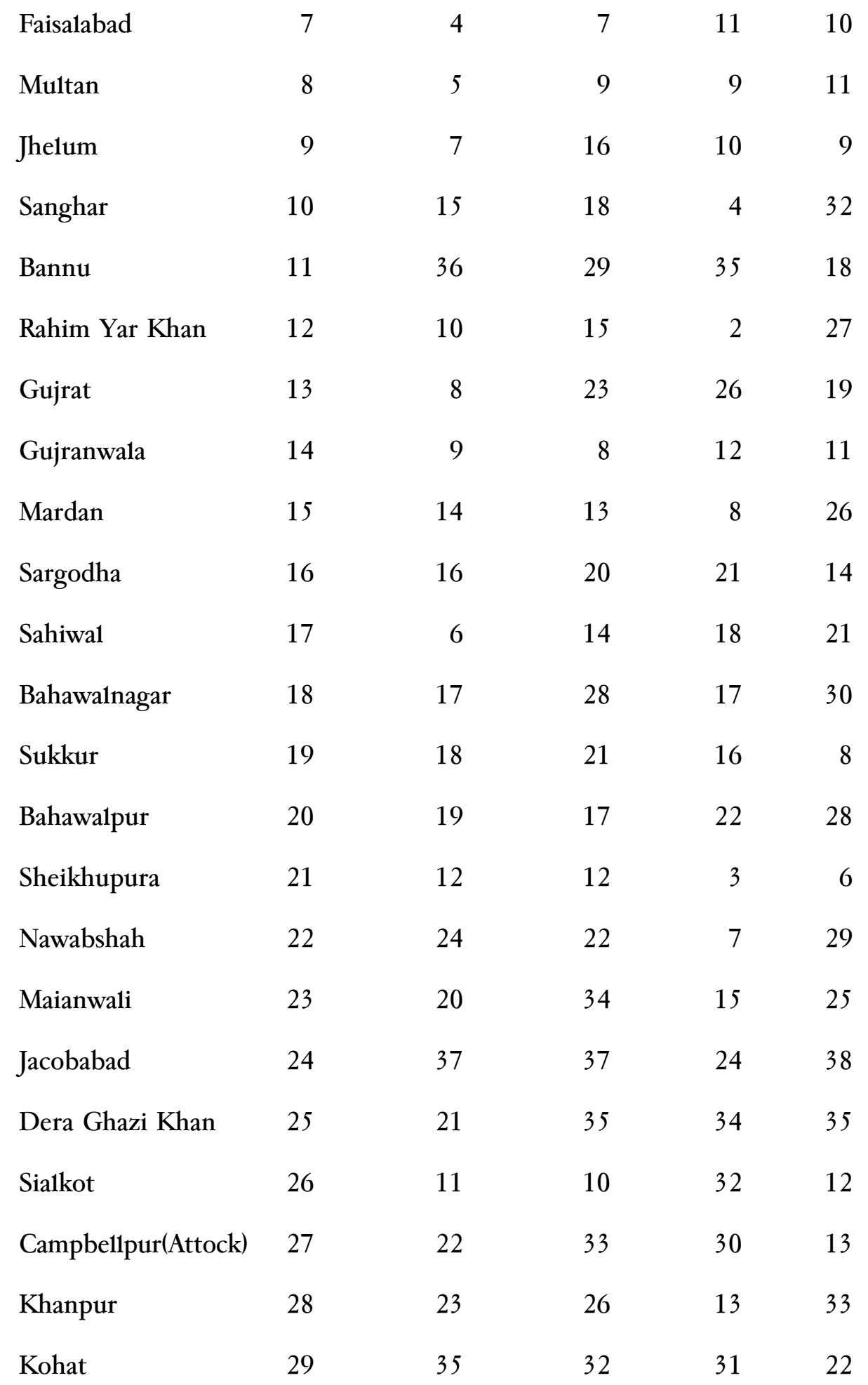


6 The Lahore Journal of Economics, Vol.1, No.1

\begin{tabular}{|c|c|c|c|c|c|}
\hline Dadu & 30 & 31 & 25 & 5 & 24 \\
\hline Muzaffargarh & 31 & 25 & 31 & 25 & 31 \\
\hline Larkana & 32 & 27 & 27 & 29 & 20 \\
\hline Jhang & 33 & 26 & 24 & 19 & 23 \\
\hline Tharparkar & 34 & 37 & 19 & 20 & 40 \\
\hline Dera Ismail Khan & 35 & 33 & 11 & 37 & 16 \\
\hline Hazara & 36 & 34 & 36 & 38 & 17 \\
\hline Thatta & 37 & 32 & 30 & 27 & 39 \\
\hline Chagai & 38 & 38 & 40 & 44 & 34 \\
\hline Kharan & 39 & 44 & 46 & 46 & 45 \\
\hline Sibi & 40 & 42 & 41 & 33 & 37 \\
\hline Zhob & 41 & 41 & 38 & 43 & 36 \\
\hline Kalat & 42 & 44 & 43 & 39 & 42 \\
\hline Loralai & 43 & 43 & 39 & 40 & 41 \\
\hline Mekran & 44 & 45 & 42 & 45 & 44 \\
\hline Kachi & 45 & 39 & 46 & 42 & 43 \\
\hline Lasbela & 46 & 60 & 45 & 41 & 46 \\
\hline
\end{tabular}

Source: EPRU: Study on industrialization potential of Selected back ward districts. A. Qutub, A.I. Hamid, A. Hussain.

Ayub Qutub ${ }^{2}$ studied the relationship between production per capita and infrastructure intensity. A logistic curve relationship emerges between infrastructure (independent variable) and productivity per capita (dependent variable). According to Qutub, for very backward districts initially marginal improvements in infrastructure do not induce a significant increase in

\footnotetext{
${ }^{2}$ Ayub Qutub: Spatial Impact of Macro Economic and Sectoral Policies. NHS Policy Study. Government of Pakistan, Environment and Urban Affairs Division (n.d.).
} 
production per capita. Once the basic infrastructure has been created (at a level of half the national average) a sharp increase in production per capita takes place. However, beyond a maximum limit $(1.7$ times the national average), the kinds of infrastructure traditionally provided in Pakistan do not seem to substantially stimulate industrial or agricultural production.

\section{Change in Spatial Concentration of Industry}

The following Table- 6 presents an interesting differentiation of economic regions on the basis of industrial growth over time.

Table-6: Value Added in Large-Scale Manufacturing by Economic Regions (\% Share of all Pakistan)

\section{A-Karachi}

(1) Karachi

\section{B-Central Punjab}

(1) Faisalabad

(2) Gujranwala

(3) Sheikhupura

(4) Lahore + Kasur

(5) Sahiwal

Total National Cores-I

\section{NATIONAL CORES}

\begin{tabular}{ccc}
\hline $1959-60$ & $1969-70$ & $1976-77$ \\
\hline 38.7 & 37.9 & 35.03 \\
\hline 38.7 & 37.9 & 35.03 \\
\hline
\end{tabular}

\begin{tabular}{rcc}
\hline 11.0 & 7.2 & 6.32 \\
2.5 & 1.1 & 1.09 \\
0.7 & 3.8 & 5.61 \\
11.9 & 6.4 & 5.47 \\
1.9 & 1.5 & 0.87 \\
\hline 28.0 & 20.0 & 19.36 \\
\hline & & \\
\hline 66.7 & 57.9 & 54.4 \\
\hline & & (more) 15
\end{tabular}

\section{LOCAL CORES}

A-Greater Federal Capital Area

(1) Rawalpindi

\begin{tabular}{ccc}
\hline $\mathbf{1 9 5 9 - 6 0}$ & $\mathbf{1 9 6 9 - 7 0}$ & $\mathbf{1 9 7 6 - 7 7}$ \\
\hline 4 & 5.6 & 8.39 \\
- & - & - \\
\hline 4 & 5.6 & 8.39 \\
\hline
\end{tabular}


8 The Lahore Journal of Economics, Vol.1, No.1

\section{B- Peshawar}

(1) Peshawar

(2) Mardan

\section{C-Multan}

(1) Multan + Vehari

Total Local Cores-II

\begin{tabular}{lll}
\hline 3.6 & 3.4 & 2.98 \\
1.3 & 1.3 & 2.60 \\
\hline 4.9 & 4.7 & 5.38 \\
\hline
\end{tabular}

\begin{tabular}{ccc}
\hline 2.5 & 4.7 & 3.2 \\
2.5 & 4.7 & 3.2 \\
\hline 11.4 & 15.0 & 17.2 \\
\hline
\end{tabular}

\section{INTER PERIPHERY}

\section{A-Punjab}
(1) Gujrat
(2) Sargodha
(3) Jhang
(4) Sialkot
(5) Muzaffargarh
(6) Rahim Yar Khan
(7) Attock
(8) Jhelum

\begin{tabular}{ccc}
\hline $\mathbf{1 9 5 9 - 6 0}$ & $\mathbf{1 9 6 9 - 7 0}$ & $\mathbf{1 9 7 6 - 7 7}$ \\
\hline 0.6 & 1.0 & 0.97 \\
0.7 & 1.3 & 1.68 \\
0.1 & - & 0.75 \\
0.8 & 0.6 & 0.56 \\
0.5 & 0.6 & 1.11 \\
2.9 & 2.2 & 2.57 \\
0.4 & 0.7 & 0.9 \\
2.6 & 3.7 & 3.29 \\
\hline 8.6 & 10.1 & 11.83 \\
\hline
\end{tabular}

\section{B- Sindh}

(1) Dadu

\begin{tabular}{lll}
\hline 0.1 & 0.6 & 3.04 \\
5.3 & 5.8 & 3.07 \\
\hline 5.4 & 6.4 & 6.11 \\
\hline
\end{tabular}


C-N.W.F.P.

D-Balochistan

Total Inner Periphery-III

\begin{tabular}{rrr}
$\begin{array}{l}\text { Nil } \\
\text { Nil }\end{array}$ & & \\
\hline 14.0 & 16.5 & 17.9 \\
\hline
\end{tabular}

A-Punjab
(1) D.G. Khan
(2) Bahawalpur
(3) Bahawalnagar
(4) Mianwali

\section{B- Sindh}
(1) Khairpur
(2) Jacobabad
(3) Sukkur + Sheikhupura
(4) Nawabshah
(5) Larkana
(6) Sanghar
(7) Tharparkar
(8) Thatta

\section{C-Balochistan}

(1) Quetta
(2) Lasbella

D-N.W.F.P.
(1) D.I. Khan
(2) Hazara
(3) Kohat
(4) Bannu

Total Outer Periphery-I

\section{OUTER PERIPHERY I}

\begin{tabular}{ccc}
\hline 1959-60 & $\mathbf{1 9 6 9 - 7 0}$ & $\mathbf{1 9 7 6 - 7 7}$ \\
\hline- & - & 0.09 \\
0.1 & 0.9 & 0.24 \\
0.1 & 0.5 & - \\
2.0 & 1.8 & 1.35 \\
\hline 2.2 & 3.2 & 1.68 \\
\hline
\end{tabular}

\begin{tabular}{ccc}
\hline 1.4 & 1.3 & 0.04 \\
- & 0.1 & - \\
0.7 & 2.0 & 1.91 \\
0.5 & 0.6 & 1.00 \\
0.1 & 0.1 & 2.47 \\
0.5 & 0.3 & - \\
0.8 & 0.8 & 0.50 \\
0.6 & 0.4 & 0.28 \\
\hline 4.6 & 5.6 & 6.20 \\
\hline
\end{tabular}

\begin{tabular}{lll}
\hline 0.4 & 0.3 & N.A. \\
0.5 & 0.4 & N.A. \\
\hline 0.9 & 0.7 & 0.35 \\
\hline
\end{tabular}

\begin{tabular}{ccc}
\hline- & 0.1 & - \\
0.6 & 1.2 & 0.90 \\
- & 0.5 & 0.70 \\
0.1 & 0.5 & 0.63 \\
\hline 0.7 & 2.3 & 2.23 \\
\hline 8.4 & 11.8 & 10.50 \\
\hline
\end{tabular}




\section{OUTER PERIPHERY II}

$\begin{array}{ll}\text { A-Punjab } & \text { Nil } \\ \text { B-Sindh } & \text { Nil }\end{array}$

\section{C-Balochistan}

(1) Quetta

\begin{tabular}{ccc}
\hline $\mathbf{1 9 5 9 - 6 0}$ & $\mathbf{1 9 6 9 - 7 0}$ & $\mathbf{1 9 7 6 - 7 7}$ \\
\hline 0.4 & 0.3 & N.A. \\
0.5 & 0.4 & N.A. \\
\hline 0.9 & 0.7 & 0.35 \\
\hline
\end{tabular}

(1) Zhob

(2) Sibi + Nasirabad + Kohlu

0.1

0.1

(3) Chagia

(4) Loralai

(5) Kalat + Khuzdar

(6) Kharan

(7) Mekran

\begin{tabular}{ccc}
\hline- & - & - \\
0.1 & 0.1 & - \\
- & - & - \\
- & - & - \\
- & - & - \\
- & - & - \\
- & - & - \\
\hline 0.1 & 0.1 & 0 \\
\hline
\end{tabular}

D-N.W.F.P.

(1) Swat

(2) Dir + Chitral

\begin{tabular}{|c|c|c|}
\hline- & - & - \\
\hline- & - & - \\
\hline 0 & 0 & 0 \\
\hline n Areas & Nil & \\
\hline 0.1 & 0.1 & 0.1 \\
\hline
\end{tabular}

Total Outer Periphery-II

Source: Ayub Qutub: Spatial Impact of Macro Economic and Sectoral Policies National Human Settlements Policy Study Government of Pakistan. Environment and Urban Affairs Division. PEPAC REPORT.

The evidence shows that in 1959-60, as much as 39 per cent of the value added in industry is accounted for by Karachi. This is followed by Lahore and Faisalabad. These three districts together accounted for 60 per cent of the value added in industry. The rest of the industry was fairly evenly distributed across the local core and the inner periphery. Over time 
the local cores, inner periphery and outer periphery all gained at the expense of the national core, although at the end of the period, Karachi still accounted for 35 per cent of value added in industry, and the Central Punjab districts constituted 19 per cent.

In Central Punjab the most rapidly industrialising district is Sheikhupura, in northern Punjab it is Jhelum, and in Sindh the most dynamic district in terms of industrial growth is Dadu.

\section{Incidence and Intensity of Poverty: The Regional Dimension}

In a recent paper, Aly Ercelawn $(1991)^{3}$ has estimated both the incidence and the intensity of poverty in each of the provinces of Pakistan for rural and urban households respectively. This has been done by first specifying the minimum expenditure required for a daily intake of 2550 calories per adult equivalent, using existing dietary patterns. The calorieexpenditure function on the basis of which the expenditure norm was derived allowed for both provincial and locational differences. The incidence of poverty indicated the percentage of households below the poverty line. 'Poverty line' is defined as the expenditure below that required for a calorific intake of 2550 calories daily per adult equivalent. The intensity of poverty estimates were based on the widely recognised proposition that an intake of between 70 to 80 per cent of the calorific norm over a sustained period constitutes a very high risk of starvation and undernourishment.

The results of Ercelawn's study suggest that in Pakistan, the incidence of poverty is highest in the Punjab and lowest in the NWFP. The percentage of households below the poverty line in rural areas are approximately 31 per cent in Punjab, 27 per cent in Balochistan, 18 per cent in Sindh and 15 per cent in NWFP. In urban areas while Punjab has the highest incidence of poverty, Sindh has the lowest. ${ }^{4}$

Thus the percentage of urban households below the poverty line are approximately 25 per cent in Punjab, 23 per cent in Balochistan, 14 per cent in NWFP and 10 per cent in Sindh.

If we define the intensity of poverty as the percentage of households unable to acquire more than 75 per cent of the calorific norm, then Ercelawn's estimates show that for the rural areas the intensity of poverty is highest in Balochistan and lowest in Sindh. The percentage of households unable to reach 75 per cent of the calorific norm in rural Pakistan are 19

\footnotetext{
${ }^{3}$ Aly Ercelawn: Undernourishment as Poverty in Pakistan, AERC, (Mimeo), 1991.

${ }^{4}$ Ibid.

${ }^{5}$ Ibid.
} 
per cent in Balochistan, 10 per cent in Punjab, 12 per cent in NWFP and 6 per cent in Sindh. For urban areas the figures are 13 per cent in Punjab, 9 per cent in Balochistan, 7 per cent in NWFP and 4 per cent in Sindh. ${ }^{6}$

\section{Towards an Alternative Planning Perspective for Regional Growth}

The achievement of regionally equitable growth means changing the conception of Pakistan's economic planning within the framework of the market mechanism. At the moment economic planning essentially involves allocating government resources amongst various "sectors" of the economy such as agriculture, industry, energy, irrigation, etc. The current planning exercise involves achieving consistency between sectoral growth targets and external and internal financial resources. Space is assumed out of the planning exercise except for sops like Special Development Programmes, which consider investment in backward areas as marginal to the overall plan. Regionally equitable development requires placing the regional dimension into the heart of the planning exercise. Each investment package must be evaluated in terms of its impact on regional growth, before designing fiscal/monetary policy incentives and institutional support.

Pakistan's experience has shown that the development of backward regions cannot be stimulated simply by giving tax incentives to entrepreneurs for investment in backward areas. The attractiveness of infrastructure and markets in the developed regions far outweighs the attractiveness of tax incentives for the entrepreneur. In rare cases where the entrepreneur does invest in the area designated "backward", (e.g., Hub Chowki) he indulges in "border hopping", i.e., he locates the unit just across the boarder between the developed and backward regions. The industrial unit draws its inputs and sells its outputs in the developed region, and therefore generates secondary multiplier effects in the developed rather than the backward region. If investment is to go deep into the backward regions to generate self-sustained growth, the development of infrastructure in these regions is essential. The question then arises, where in the vast "backward" region to set up the infrastructure and how much? A regional planning exercise would involve mapping the economic and social infrastructure, geographic location of markets by size and source of raw materials. On the basis of such a "map", potential growth NODES could be specified in the backward region. These would be locations which on the basis of some existing infrastructure, closeness to a local market, or raw material deposit, qualify for supplementary infrastructural investment by the government. The first step towards specifying such growth nodes has already

${ }^{6}$ Ibid. 
been taken with our study on Industrialisation Potential of Selected Districts. This study has proposed growth nodes in the following districts: Khairpur, Nawabshah and Sanghar in Sindh; D.G. Khan, Muzaffargarh and Bhakkar in the Punjab. A similar exercise could be conducted for all the backward regions of the country. The nodes could be specified in such a way that as growth begins to occur, they begin to interact in terms of factor markets, thereby generating self-sustained growth diffusion in the backward areas.

\section{Conclusion}

Just as in the designing of fiscal/monetary policy incentives the regional dimension needs to be taken into account in the same way in the design of poverty alleviation measures by the government and NGOs, differences in the level of poverty and the dynamics of poverty creation as between provinces should perhaps be an essential consideration. 
14 The Lahore Journal of Economics, Vol.1, No.1

\section{References}

ERCELAWN, Aly, 1991. Undernourishment as Poverty in Pakistan, Mimeo, AERC.

HAMID, Naved and HUSSAIN, Akmal, Winter 1976. Regional Inequalities and Capitalist Development, The Case of Pakistan, in Pakistan Economic and Social Review, Special Issue.

QUTUB, Ayub. Spatial Impact of Macro Economic and Sectoral Policies, NHS Policy Study, Government of Pakistan, Environment and Urban Affairs Division (n.d.).

QUTUB, A., HAMID, I., HUSSAIN, A., "Study on Industrialisation Potential of Selected Districts", report submitted to NDFC by EPRU. 